\title{
A Particular Silhouette of Human-Influenced Coconut Research \& 8 Q Trees in Hindu Bali, Indonesia: An ethnobotanical field note
}

\author{
Rie Miyaura, Tomoko Ohno, Hisayuki Maenaka, \\ Ketut Sumiartha, and Hirofumi Yamaguchi
}

\section{Research}

\begin{abstract}
In Hindu Bali, coconut trees near human settlements exhibit a particular silhouette. To understand the relationship between human activity and the landscape created by plant usage, we analyzed the extent of the cut-leaved coconut canopies and consumption pattern of coconut leaflets for religious purposes on Bali Island. Cut-leaved coconut canopies were identified in $78 \%$ of the 18 sites investigated, and $22 \%$ of coconut trees had cut leaves. Coconut leaflets, young and old, were gathered from live trees and frequently used for many offerings such as canang, penjor, and sanggah cucuk for Dewi Sri as part of plant decorations made with various colorful flowers and ornamental tree leaves. Balinese people still make traditional offerings with intact plant materials, although recently coconut leaflets are increasingly sold in markets in urban areas. We conclude that this particular coconut silhouette is a result of human ritual activities stemming from the Balinese culture.
\end{abstract}

\section{Introduction}

The island of Bali, Indonesia, is well known for its gardens, architecture, and art expressing the spirit of a form of Hinduism that differs from that in India and Nepal (Ramseyer 1977). Balinese people live in a web of relationships, both sekala (tangible, visible) and niskala (intangible, invisible) (Brinkgreve \& Stuart-Fox 1992, Eiseman 1989). Harmonizing these relationship elements, Balinese people place great value on prayer and the performance of rituals, which can be observed daily all over the island. Plants are integral part of these rituals, serving as a means to connect humans as sekala and the supernatural as niskala.
Ethnological studies in Bali have focused on the island's religion and rituals (Bateson \& Mead 1942, Belo 1953, Covarrubias 1937, Fujioka 1968, Geertz 1973), and some researchers have written in detail about the offerings used (Brinkgreve 1997, Brinkgreve \& Stuart-Fox 1992, Eiseman 1989, Hooykaas 1973, Ottino 2000, Ramseyer 1977, Stuart-Fox 1974, Yoshida 1999). However, dynamic relationships among different peoples, religions, cultures, plant use, and the environment as a field of ethnobiology are still not well-studied.

In the ancient Near-East, Arabia, Greece, Egypt, and China, palm trees are considered "the tree of life," symbolizing regeneration and return to perfection (Cooper 1978). Palm trees are believed to form the central axis for the flow of energy between supernatural realms and the human world (De Carvalho 2011). The coconut (Cocos nucifera L.) is one of the most important palms used in dai-

\section{Correspondence}

Rie Miyaura, Department of International Biobusiness Studies, Faculty of International Agriculture and Food Studies, Tokyo University of Agriculture, Tokyo, JAPAN. mia@nodai.ac.jp

Tomoko Ohno, Graduate School of Human Development and Environment, Kobe University, Kobe, JAPAN.

Hisayuki Maenaka, Green Earth Network, Certified NPO Corporation, Osaka, JAPAN.

Ketut Sumiartha, Study Program of Agroeco Technology, Faculty of Agriculture, Udayana University, Badung, Bali, INDONESIA.

Hirofumi Yamaguchi, Department of Human and AnimalPlant Relationships, Faculty of Agriculture, Tokyo University of Agriculture, Kanagawa, JAPAN.

Ethnobotany Research \& Applications 14:405-421 (2015)

Published: 22 December 2015

http://dx.doi.org/10.17348/era.14.0.405-421 
Iy life in Bali and in other tropical regions (Covarrubias 1937, Giambelli 1992, Harries et al. 2004) and is symbolized as a tree of life similar to banana (Musa acuminata $\times$ balbisiana Colla) and bamboo (Arimasa 2010). For the Balinese people, the reason that coconuts have their roots in the soul of the culture can be understood from the legend of Mayadanawa, the male and female twins who were born as the first raja (king) from inside a coconut flower (Belo 1935). Coconuts in Nusa Penida and Bali have been used as a metaphor of the life cycle of human beings, although with slight ethnic differences in the rituals. The life span of the coconut is similar to the human life span, and its developmental stages are very similar to the four major human events of birth, maturity, death, and deification (Giambelli 1992). In Bali, coconuts exhibit a particular canopy shape not seen in other tropical areas, as seen in the photographs of Covarrubias (1937) and Haks and Wichlin (2011). Coconut leaves have become part of important ritual offerings such as canang, penjor, and sanggah cucuk for Dewi Sri (the goddess of rice) in paddy fields (Couteau 2005, Covarrubias 1937).
Although ethnobotanical diversity in daily plant use and human life has been monitored in Bali (Arimasa et al. 2007, Astuti et al. 2000, Eko 1998), there has been little research on the precise inter-relationship between human cultural activity and environment including the landscape. The present study focuses on the coconut palm as one of the plants highly connected with human life and aims to clarify the usage, local names, leaflet collection methods, geographical distribution, associated plant species used for rituals, and the formation of unique landscapes in Bali.

\section{Methods}

\section{Study area}

The Indonesian province of Bali includes the main island of Bali and a number of smaller islands including Nusa Penida. The province covers a total area of $5636 \mathrm{~km}^{2}$ (Figure 1) and in 2010 had a total population of 3.89 million people living in 228,000 households within nine regencies (Bali Statistics 2014). Currently, the population in-

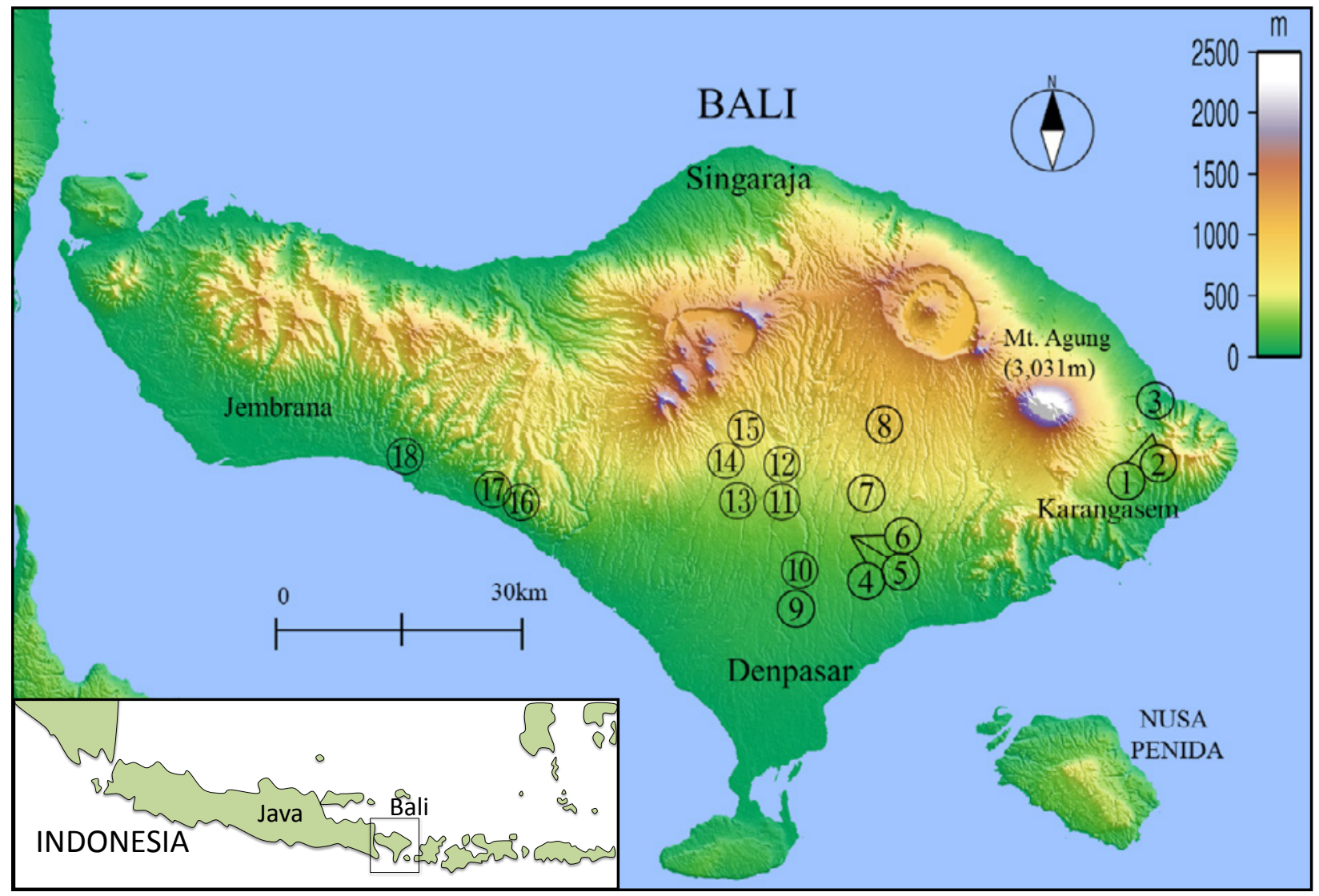

Figure 1. Survey sites in Bali, Indonesia: Mangsul (1),(2), Labasari (3), Banjar Sakti (4) (5) (6), Ceking (7), Jasan (8), Blumbungan (9) (10), Kuum (11), Banjar Baru (12), Pohgending (13), Mangesta (14), Jatiluwih (15), Gumbrih (16), Pangyangan (17), and Yeh Embang Kangin (18). See Table 1 for more site location details. 


\section{Miyaura et al. - A Particular Silhouette of Human-Influenced Coconut Trees in 407 Hindu Bali, Indonesia}

\begin{tabular}{|c|c|c|c|c|c|}
\hline \multirow{3}{*}{$\begin{array}{l}\text { Ecological le } \\
\text { Landscape } \\
\text { Ecosystems } \\
\text { Community }\end{array}$} & \multicolumn{5}{|c|}{ Landscape } \\
\hline & \multicolumn{3}{|c|}{ Agroecosystems } & \multicolumn{2}{|c|}{ Non-agroecosystems } \\
\hline & Agroforestry & Crop fields & Home gardens & Rural areas & Urban areas \\
\hline $\begin{array}{l}\text { Individuals } \\
\text { (major crop } \\
\text { species) }\end{array}$ & $\begin{array}{c}\text { cloves, } \\
\text { durians } \\
\text { jackfruit, } \\
\text { cacao }\end{array}$ & $\begin{array}{l}\text { paddy rice } \\
\text { upland crops } \\
\text { vegetables }\end{array}$ & $\begin{array}{c}\text { fruit tree } \\
\text { medicinal herbs } \\
\text { timber tree }\end{array}$ & \multicolumn{2}{|c|}{$\begin{array}{l}\text { ornamental plant } \\
\text { street plant }\end{array}$} \\
\hline
\end{tabular}

Figure 2. Ecological features of the coconut tree growing sites.

cludes 3.24 million Hindus (83.3\%), 0.52 million Muslims $(13.4 \%)$, and others, compared with a Hindu population of 1.06 million $(97.3 \%)$ in 1930 (Swellengrebel 1960). The proportion of Hindus has specifically decreased in areas such as the capital Denpasar regency and the Jembrana regency near Java Island. In 2010, Hindus made up only $28.6 \%$ of the population in Denpasar and $26.6 \%$ in Jembrana, compared with $92.3 \%$ and $79.3 \%$, respectively, in 1930.

The island is covered by human-influenced areas and fragmented natural vegetation in three climatic zones: (1) tropical rainforest climate with dense stands of evergreen and semi-evergreen rainforest in the center of the island; (2) tropical monsoon climate with moist and dry deciduous forests; and (3) savanna climate with grassland, dry scrubland, and palm groves in the driest areas in the north and northeast lowlands (Heim 2015). The evergreen lowland rainforests dominated by Dipterocarpus spp. cover areas up to $1200 \mathrm{~m}$ in altitude, and the montane forests consist of tree ferns such as Cyathea latebrosa (Wall. ex Hook.) Copel. or Casuarina junghuhniana Miq. There are two seasons: the dry season from May to September and the wet season from October to April. Coconuts grow in human-influenced habitats such as the levees of crop fields or rice paddies, upland crop fields, and in the agroforests on mountain slopes (Figure 2). They also grow along beaches, in home gardens close to houses, and along roadsides in rural and urban areas throughout the islands. The fruit are used for many purposes including copra production, cooking, and drinking.

\section{Data collection}

After a preliminary field survey in March 2009, a 7-day field survey was conducted on the Bali mainland in November 2012. The aims of the survey were to examine the diversity of the coconut tree canopy, to investigate the plant materials used for canang, and to interview local residents about the use of coconut leaves for canang, penjor, and other kinds of offerings. Eight of the nine regencies in the area were visited (the northwest Bleleng regency was not included), and a diversity analysis was conducted on the coconut tree canopy in 18 sites in the five regencies of Karangasem, Gianyar, Badung, Tabanan, and Jembrena (Figure 1, Table 1), which together cover $68 \%$ of the total land area of Bali. The sites were selected based on a perceived similar coconut tree density in the landscape, balanced site characteristics, and accessibility with the limited time constraint of the survey. While there were many places where coconut trees are planted, places with only a few coconut trees were not chosen. The numbers of cutleaved coconut trees were counted among the coconut trees visible with the naked eye from a stand in each area (site). The survey sites ranged from sea level lowland to $743 \mathrm{~m}$ above sea level so did not include coconut trees growing at the highest altitudes of up to $1037 \mathrm{~m}$ above sea level at the foot of the Kintamani highlands. Interviews were conducted in the five regencies mentioned above and also in the Bangli regency.

In total, 27 local people were interviewed (52\% female, $48 \%$ male; $63 \%$ older than 50 years, $37 \%$ aged $20-50$ years). The respondents included people who use offerings and people who make and sell coconut leaves in the local markets and villages. The people were asked about gathering methods and the uses of coconut leaves, the local names for the plants, the measurement of coconut leaflets used for offerings, and general information about ritual plant use.

In order to clarify the diversity of plant materials used and the design of offerings, 36 canang offerings ( $a d$ hoc) were sampled. These offerings were placed at houses or along roadsides.

Finally, a search and analysis was conducted on photographs in the Sasuke Nakao Slide Database (Osaka Prefecture University, Library \& Science Information Center) and photographs in books describing Balinese life (Agung 1991, Covarrubias 1937, Hooykaas 1973, Krause 1998, Ramseyer1977, Vickers 1989). 
Table 1. Frequency of coconut trees with cut leaves in a survey site in Bali, Indonesia.

\begin{tabular}{|c|c|c|c|c|c|c|c|}
\hline \multirow[b]{2}{*}{ Site } & \multicolumn{3}{|c|}{ Trees } & \multicolumn{3}{|c|}{ Site locations } & \multirow[b]{2}{*}{$\begin{array}{l}\text { Elevation } \\
(\mathrm{m})\end{array}$} \\
\hline & $\begin{array}{c}\text { Total } \\
\text { observed }\end{array}$ & $\begin{array}{l}\text { Cut } \\
\text { leaves }\end{array}$ & $\begin{array}{l}\% \text { cut } \\
\text { leaves }\end{array}$ & $\begin{array}{c}\text { Desa } \\
\text { (village) }\end{array}$ & $\begin{array}{c}\text { Kecamatan } \\
\text { (district) }\end{array}$ & $\begin{array}{l}\text { Kabupaten } \\
\text { (regency) }\end{array}$ & \\
\hline 1 & 19 & 7 & 37 & \multirow{2}{*}{ Mangsul } & \multirow{3}{*}{ Abang } & \multirow{3}{*}{ Karangasem } & 327 \\
\hline 2 & 21 & 6 & 29 & & & & 327 \\
\hline 3 & 29 & 0 & 0 & Labasari & & & 99 \\
\hline 4 & 19 & 10 & 53 & \multirow{3}{*}{ Banjar Sakti } & \multirow{3}{*}{ Ubud } & \multirow{5}{*}{ Gianyar } & 264 \\
\hline 5 & 25 & 13 & 52 & & & & 264 \\
\hline 6 & 57 & 14 & 24 & & & & 264 \\
\hline 7 & 43 & 7 & 16 & Ceking & \multirow{2}{*}{ Tegalalang } & & 443 \\
\hline 8 & 110 & 6 & 6 & Jasan & & & 743 \\
\hline 9 & 67 & 0 & 0 & \multirow{2}{*}{ Blumbungan } & \multirow{2}{*}{ Abiansemal } & \multirow{2}{*}{ Badung } & 121 \\
\hline 10 & 31 & 0 & 0 & & & & 176 \\
\hline 11 & 32 & 6 & 19 & Kuum & Mengwi & \multirow{5}{*}{ Tabanan } & 354 \\
\hline 12 & 32 & 12 & 38 & Banjar Baru & Marga & & 512 \\
\hline 13 & 56 & 33 & 59 & Pohgending & \multirow{3}{*}{ Penebel } & & 390 \\
\hline 14 & 16 & 16 & 100 & Mangesta & & & 652 \\
\hline 15 & 74 & 21 & 28 & Jatiluwih & & & 648 \\
\hline 16 & 34 & 6 & 18 & Gumbrih & \multirow{2}{*}{ Pekutatan } & \multirow{3}{*}{ Jembrana } & 17 \\
\hline 17 & 19 & 0 & 0 & Pangyangan & & & 22 \\
\hline 18 & 26 & 1 & 3.8 & Yeh Embang Kangin & Mendoyo & & 35 \\
\hline $\mathrm{Av}$ & 39 & 8.8 & 22 & & & & \\
\hline SD & 25 & 8.6 & - & & & & \\
\hline
\end{tabular}

\section{Results}

\section{Cut-leaved coconut canopy and gathering of leaflets}

The harvesting of coconut leaves in Bali results in a particular individual tree canopy shape (Figure 3). The cutleaved canopy is characterized by trimmed leaves with leaflets (pinnae) removed from intermediate portions of the main leaf rib (Figure 4A). The example shows a leaf with 44 leaflets harvested from each side for use as offerings. This resulting appearance is clearly different from those leaves with reduced leaflets (Figure 4B) secondary to consumption by the Asiatic rhinoceros beetle (Oryctes rhinoceros L., 1758), or other insects.

In the 18 sites examined, the average number of coconut trees per site was 39 , while the average number of cut-leaved coconut trees was 8.8 (Table 1). A cut-leaved coconut canopy was found in 14 of the 18 sites surveyed $(78 \%)$. On average $22 \%$ of coconut trees had cut leaves. The interviews (Table 2) revealed that Balinese people name coconuts according to part and growth stages. The leaf has three names: busung, slepan, and danyuh. Busung refers to the white- or yellow-colored young leaflets folded inside a spear leaf within a month after sprouting. These are used to make canang and many types of decorations. Slepan refers to the green leaflets older than busung, which are used to make different types of offerings. Danyuh refers to the oldest, brown, dry leaflets, which are used to start fires for cooking. Keloping (dried leaf bracts) are used for fires but not for offerings. The diversity of the naming and usage based on the developmental stage of this one plant species demonstrates the importance of coconut trees in Balinese life.

Balinese people harvest leaves in two ways: (1) they cut off the new shoots from leaves covered by sacks, or (2) they cut some leaflets of a young leaf midway through the development of the coconut trees. The first harvesting method results in a form with the tip cut off, and the second method results in the leaf shape shown in Figure $4 \mathrm{~A}$. The busung or slepan is gathered by cutting leaflets from the tree with a sabit (a farmer's knife), after climbing the tree using singkad (figure-eight shaped loop made from banana leaf sheaths) and using the leaf scars as foot holds (Figures 5 and 6 ). The removal of pinnae from the middle part of the leaves results in the cut-leaved coconut canopy. 


\section{Miyaura et al. - A Particular Silhouette of Human-Influenced Coconut Trees in Hindu Bali, Indonesia}
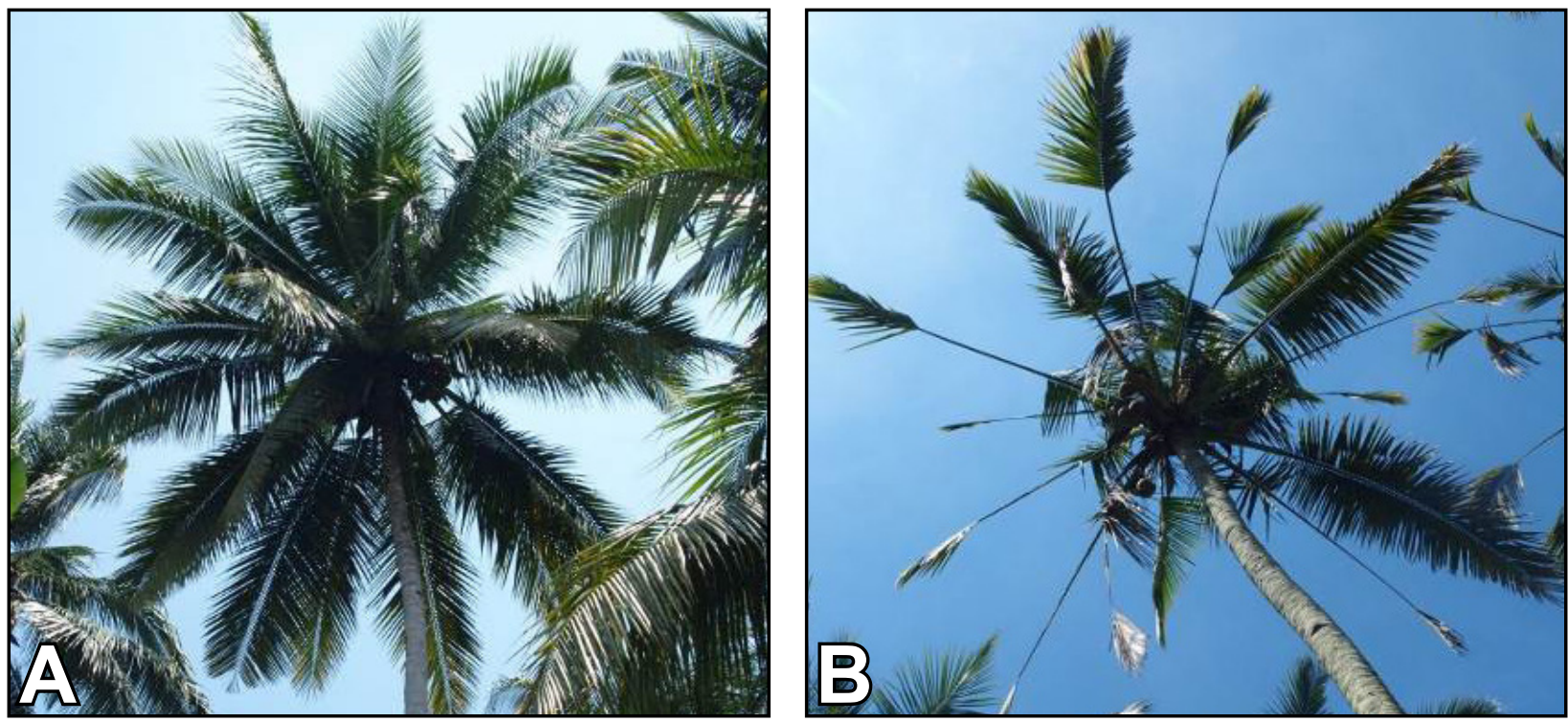

Figure 3. Normal tree canopy (left) and cut-leaved canopy (right) of coconuts in Bali, Indonesia.
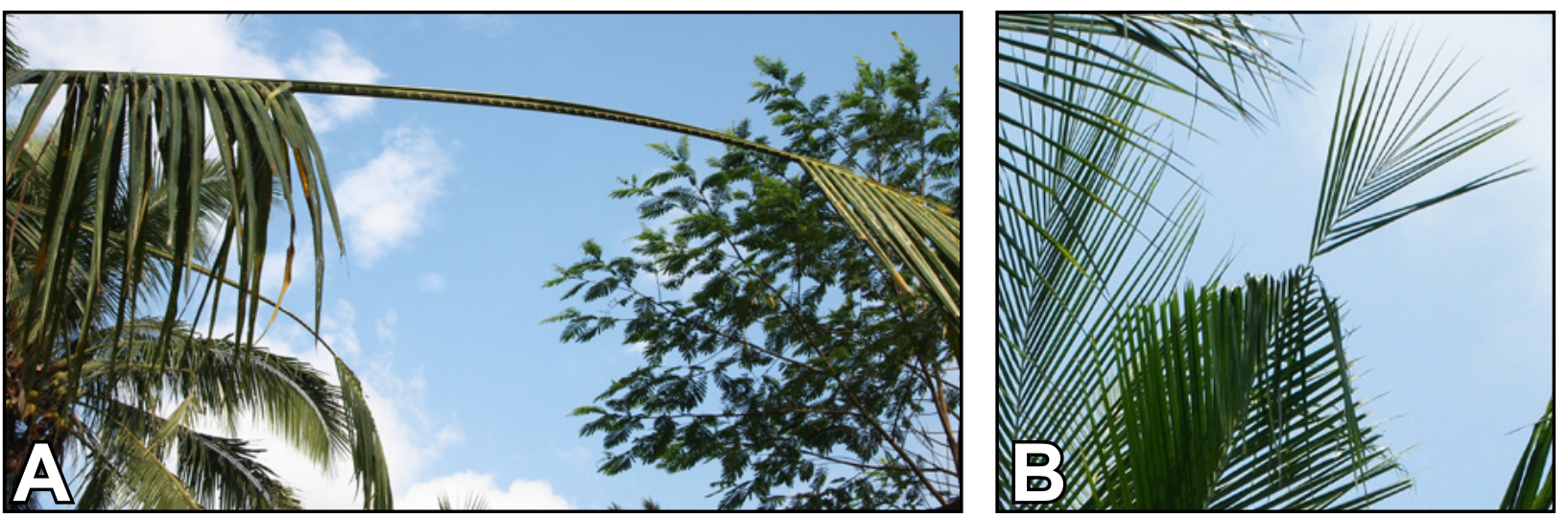

Figure 4. Coconut leaf with cut-leaflets by humans (A), and leaf damaged by coconut black beetles (B) in Bali, Indonesia.

Table 2. Local name and usage of coconut in Kabupaten Gianyar, Bali, Indonesia.

\begin{tabular}{|l|l|l|l|}
\hline Part & Bali name & Growth condition & Usage \\
\hline \multirow{4}{*}{ Tree } & tubuh & Young tree before producing fruit & \\
\cline { 2 - 4 } & kelapa & Adult tree producing fruit & \\
\hline \multirow{5}{*}{ Leaf } & busung & $\begin{array}{l}\text { White or yellow colored young leaflets (pinna) in- } \\
\text { side in a leaf-booth within a month after sprouting }\end{array}$ & Offering \\
\cline { 2 - 4 } & slepan & Green colored leaflets fully open & Square shaped plate for offerings \\
\cline { 2 - 4 } & danyuh & Brown colored dry leaflet & Fuel for cooking \\
\hline \multirow{5}{*}{ Leaf bract } & keloping & & Fuel for cooking \\
\hline & bungsil & $\begin{array}{l}\text { Youngest fruit before accumulating liquid endo- } \\
\text { sperm }\end{array}$ & \\
\cline { 2 - 4 } & bungkak & Developing liquid endosperm stage after bungsil & The fluid is used for purifying rituals \\
\cline { 2 - 5 } & kuwud & Fresh solid endosperm developing stage & \\
\cline { 2 - 4 } & nyuh & $\begin{array}{l}\text { Developing solid endosperm stage with less liquid } \\
\text { endosperm }\end{array}$ & Cooking \\
\hline
\end{tabular}





Figure 5. Climbing a coconut tree (A) with feet protected from slipping using a slingkad made from an old banana leaf sheath (B) in Bali, Indonesia.
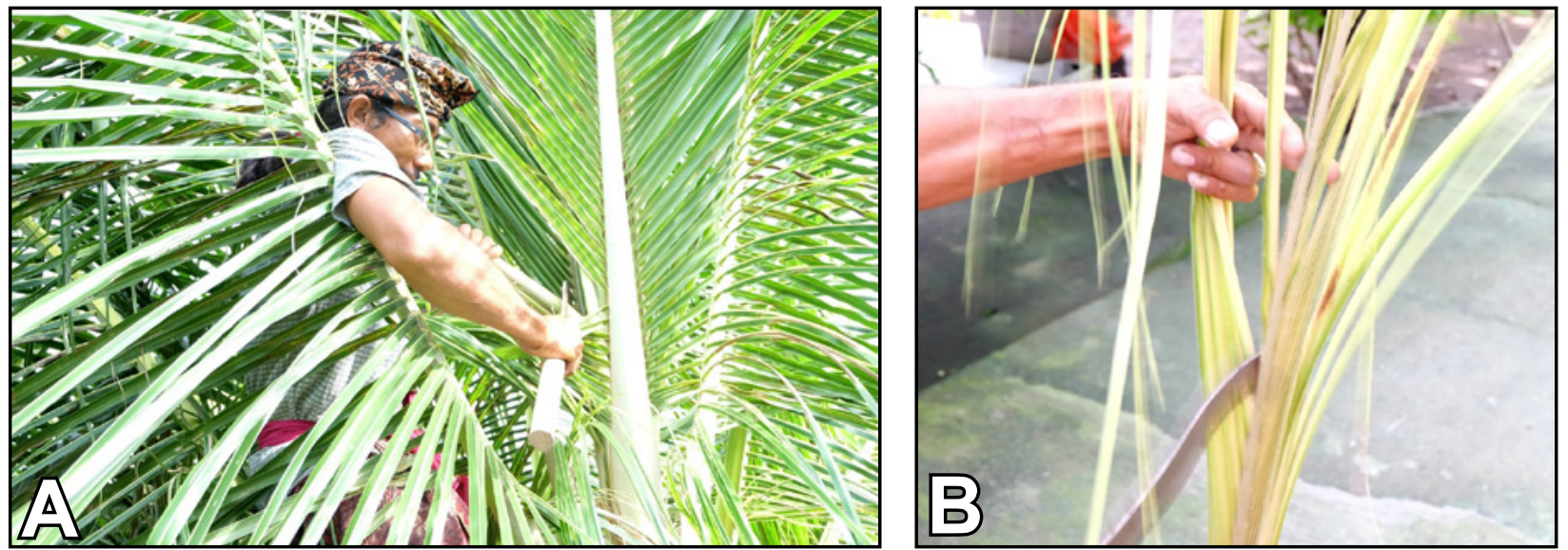

Figure 6. Cutting coconut leaflets: busung $(\mathbf{A})$ and slepan

Coconut leaflets are used both daily and on special occasions, and this cut-leaf silhouette among the coconut trees can be seen in many easily accessible areas but not on slopes or cliffs that are dangerous or difficult to access. Traditionally, people would climb a coconut tree to gather leaflets for their own offerings, but now they often pay a neighbor who is good at climbing. The cost varies among the villages, ranging from 3300 Rupiah (US\$ 0.33)
(2000 Rupiah per climb with one coconut fruit for around 1300 Rupiah) to 5000 Rupiah (US \$0.50) without fruit, depending on the area. A climber gathers a maximum of three leaves per tree at one time. A robust male worker can climb as many as 50 trees in one day. Coconut leaflets are often transported within the island and sold as a commodity at city shops (Figures 7 and 8 ). In a local daily goods shop in Ubud (Table 3), there were two types of

Table 3. Coconut leaflets sold at a shop on 15 November 2012 in Ubud, Bali, Indonesia. See also Figure 7.

\begin{tabular}{|l|l|c|c|c|c|r|r|}
\hline \multirow{2}{*}{$\begin{array}{l}\text { Leaflet } \\
\text { type }\end{array}$} & \multirow{2}{*}{$\begin{array}{l}\text { Leaflet } \\
\text { color }\end{array}$} & & \multicolumn{2}{|c|}{ Leaflet size $(\mathbf{c m})$} & \multicolumn{3}{|c|}{ Leaflet bunches } \\
\cline { 5 - 9 } & Length & Fold width & Diameter $(\mathbf{c m})$ & Leaflets & \multicolumn{2}{|c|}{ Price/bunch } \\
\cline { 5 - 9 } & A Slepan & green & 120 & 2.5 & 9 & Rupiah & U.S.\$ \\
\hline B Busung & light green & 120 & 2.5 & 7 & 70 & 10,000 & 1.0 \\
\hline C Slepan & dark green & 150 & 3.5 & 9 & 100 & 5,000 & 0.5 \\
\hline
\end{tabular}



Hindu Bali, Indonesia



Figure 7. Coconut leaflets sold at a shop in Ubud, Bali, Indonesia. Types: slepan (A, C) and busung (B). See Table 3. 


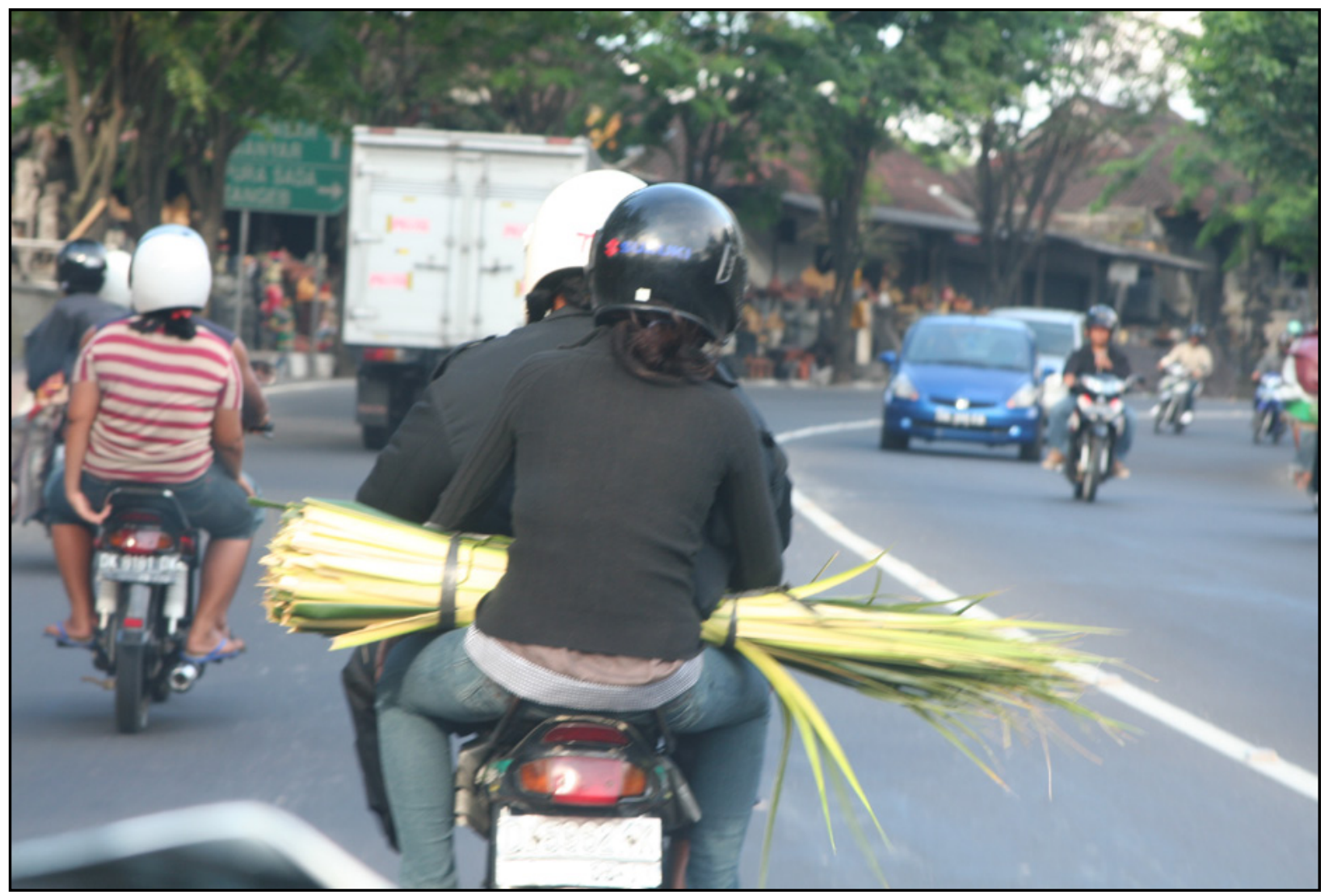

Figure 8. Transportion of coconut leaflets on the back seat of a motorcycle in Bali, Indonesia.

slepan for sale, with different length, volume, and price. A bunch of busung was more expensive than slepan. The price of one leaflet of busung was about 140 Rupiah (US\$ 0.014), and slepan was 50 Rupiah (US\$ 0.005).

\section{Coconut offerings}

Balinese people usually offer several kinds of plant materials such as coconut, banana leaf, rice, and flowers, all with special meanings to the gods. Coconut leaves, fruit, and liquid endosperm (water in fruit) are used for rituals (Figures 9-13) both on a daily basis (canang), and for special occasions (e.g., penjor, sanggah cucuk). To make the offerings, coconut, puring (Codiaeum variegatum (L.) Rumph. ex A.Juss.), and endong (Cordyline fruticosa (L.) A.Chev.) are traditionally gathered from trees beside houses. However, people in the city purchase these plant materials from local markets or nearby shops.

\section{Daily rituals}

Canang is commonly seen on the streets of Bali. For everyday prayers in the morning and evening, canang, varying from small to large, are prepared with plant materials and specially folded coconut leaves. Based on 36 samples of canang displayed in a public place during the survey, there are two main types of canang. Canang sari (50\%, including an octagonal petaline shape [28\%] and a crucifer shape [22\%]) and canang ceper (39\%) were most commonly observed, followed by canang tankih and canang tamas (Figure 9). The canang consisted of three parts: a frame, porosan, and flowers and leaves as decoration (Table 4). The base of canang sari is made with young coconut leaflets. The side of canang ceper is made of a coconut leaflet cut in half lengthwise, with the bottom overlapped at the edge to make a flat plate (Figure 10). A very thin split bamboo skewer is used to pin the coconut leaf to the bottom part. The canang ceper is a square-shaped frame of coconut leaflets with a base of coconut or banana leaf, arranged with flowers and incense sticks offered to the gods (Figure 11). The most frequent plant material used in 36 canang samples was coconut leaflets $(97 \%)$, followed by fragrant leaves of pandan (Pandanus tectorius Parkinson ex Du Roi, 94\%), pacah (Impatiens balsamina L., 69\%), gumitir (Tagetes erecta L., 69\%), and kembang kertas (Bougenvillea sp., $36 \%)$.

The two canang types required leaflets of different lengths. For example, the frame of canang sari is made with $20 \mathrm{~cm}$ of coconut leaflet while canang ceper is made with $40 \mathrm{~cm}$ of coconut leaflet and $10 \mathrm{~cm}$ squares of ba- 

Hindu Bali, Indonesia
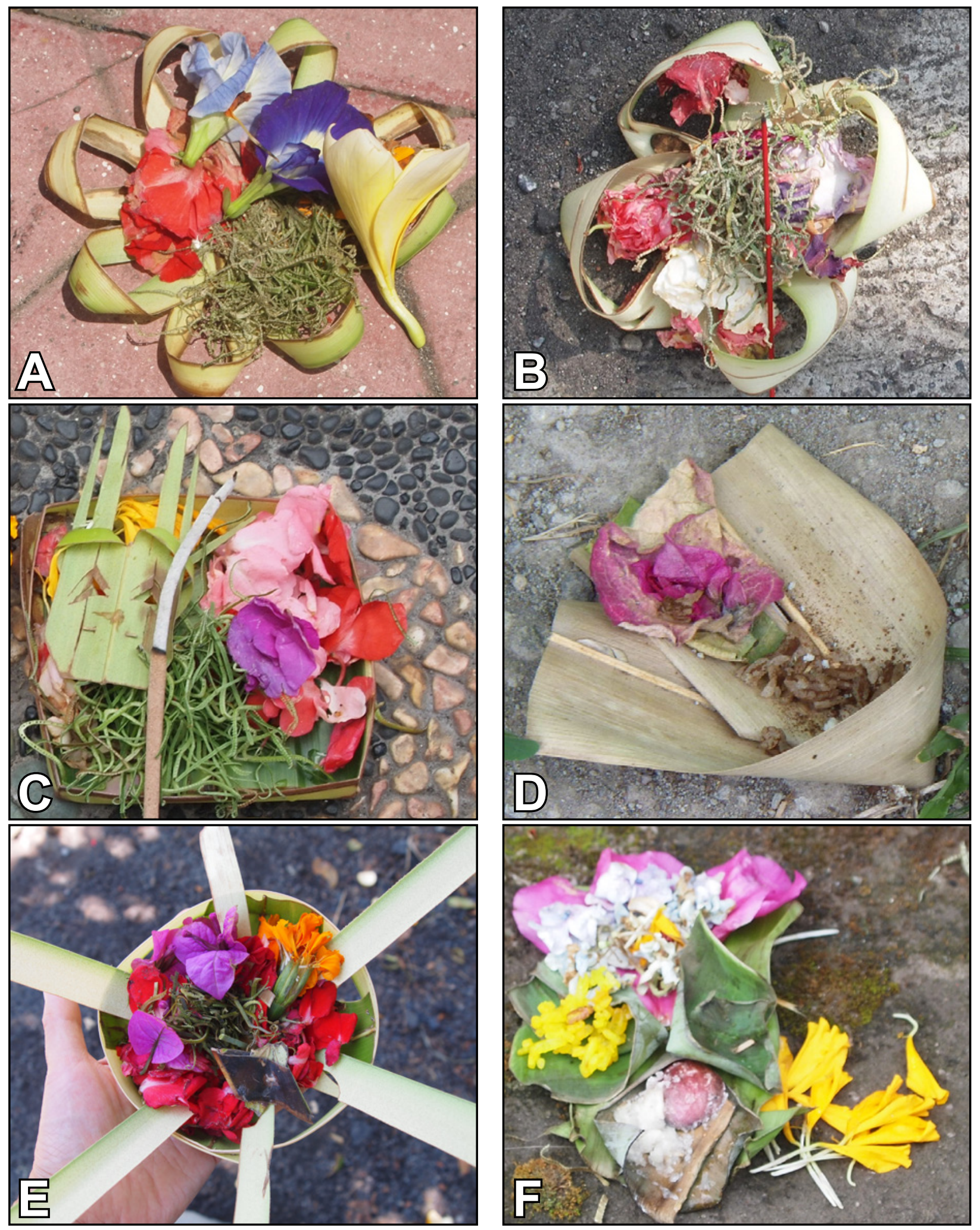

Figure 9. Types and frequency of canang from 36 samples found in public places in November 2012 in Bali, Indonesia. (A) canang sari: octagon petaline shape, 28\%; (B) canang sari: crucifer shape, 22\%; (C) canang ceper, 39\%; (D) canang tangkih, $6 \%$; $(E)$ canang tamas, $3 \%$; and $(F)$ other, $3 \%$. 
Table 4. Major plant materials used for canang offerings observed on a day in November, 2012, in Bali, Indonesia. ${ }^{1}$ Planted only in the highland but distributed everywhere through the market in Bali. ${ }^{2}$ Planted and used only in the highland area. ${ }^{3}$ Banana leaflets used for the bottom of canang ceper connected by bamboo sticks, semat. ${ }^{4}$ Bar refers to plants not counted.

\begin{tabular}{|c|c|c|c|c|c|c|c|c|c|c|c|c|c|c|c|}
\hline \multirow{2}{*}{ 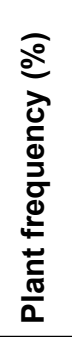 } & \multicolumn{2}{|r|}{ Plant names } & \multicolumn{4}{|c|}{ Plant origin } & \multicolumn{6}{|c|}{ Plant part used } & \multicolumn{3}{|c|}{ Purpose } \\
\hline & Bali & Scientific [Family] & 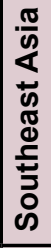 & $\begin{array}{l}\frac{\pi}{0} \\
\frac{9}{4} \\
\frac{0}{9} \\
\frac{1}{3}\end{array}$ & 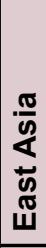 & 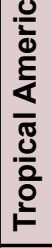 & 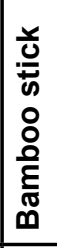 & 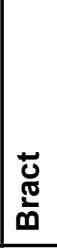 & $\begin{array}{l}\vdots \\
\vdots \\
\frac{0}{L} \\
\end{array}$ & $\stackrel{4}{\mathbb{\Phi}}$ & $\bar{\pi}$ & 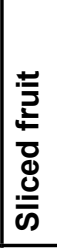 & 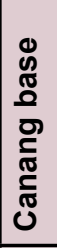 & 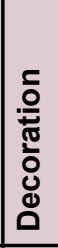 & 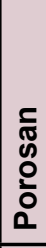 \\
\hline 97.2 & nyuh & Cocos nucifera L. [Arecaceae] & $\mathrm{X}$ & & & & & & & $\mathrm{X}$ & & & $\mathrm{X}$ & & $\mathrm{X}$ \\
\hline 94.4 & pandan & $\begin{array}{l}\text { Pandanus tectorius Parkinson ex } \\
\text { Du Roi [Pandanaceae] }\end{array}$ & $\mathrm{X}$ & & & & & & & $\mathrm{X}$ & & & & $\mathrm{X}$ & \\
\hline 69.4 & pacah & $\begin{array}{l}\text { Impatiens balsamina L. } \\
\text { [Balsaminaceae] }\end{array}$ & $\mathrm{X}$ & $x$ & & & & & $x$ & & & & & $x$ & \\
\hline 69.4 & gumitir & Tagetes erecta L. [Asteraceae] & & & & $x$ & & & $\mathrm{X}$ & & & & & $\mathrm{X}$ & \\
\hline 36.1 & kembang kertas & Bougainvillea sp. [Nyctaginaceae] & & & & $\mathrm{x}$ & & $x$ & $\mathrm{X}$ & & & & & $x$ & \\
\hline 13.9 & jepun & Plumeria sp. [Apocynaceae] & & & & $x$ & & & $\mathrm{X}$ & & & & & $\mathrm{X}$ & \\
\hline 13.9 & bunga pelung $^{1}$ & $\begin{array}{l}\text { Hydrangea macrophylla (Thunb.) } \\
\text { Ser. [Hydrangeaceae] }\end{array}$ & & & $x$ & & & & $x$ & & $x$ & & & $x$ & \\
\hline 8.3 & soka & Ixora coccinea L. [Rubiaceae] & & $\mathrm{x}$ & & & & & $\mathrm{X}$ & & & & & $\mathrm{x}$ & \\
\hline 5.6 & pucuk kuning & Allamanda sp. [Apocynaceae] & & & & $x$ & & & $X$ & & & & & $\mathrm{X}$ & \\
\hline 5.6 & biyu & Musa sp. [Musaceae] & $x$ & & & & & & & & & $x$ & & $x$ & \\
\hline 5.6 & cepaka & $\begin{array}{l}\text { Magnolia champaca (L.) Baill. ex } \\
\text { Pierre [Magnoliaceae] }\end{array}$ & $\mathrm{X}$ & & & & & & $x$ & & & & & $x$ & \\
\hline 2.8 & nusa indah & Mussaenda sp. [Rubiaceae] & $\mathrm{X}$ & $x$ & $x$ & & & $x$ & & & & & & $x$ & \\
\hline 2.8 & intaran & $\begin{array}{l}\text { Azadirachta indica A.Juss. } \\
\text { [Meliaceae] }\end{array}$ & & $x$ & & & & & & $\mathrm{X}$ & & & & $x$ & \\
\hline 2.8 & pucuk barak $^{2}$ & $\begin{array}{l}\text { Rhododendron indicum (L.) } \\
\text { Sweet [Ericaceae] }\end{array}$ & & & $\mathrm{X}$ & & & & $\mathrm{X}$ & & & & & $x$ & \\
\hline 2.8 & teleng & Clitoria ternatea L. [Fabaceae] & $\mathrm{X}$ & & & & & & $\mathrm{X}$ & & & & & $\mathrm{X}$ & \\
\hline-4 & biyu $^{3}$ & Musa sp. [Musaceae] & $x$ & & & & & & & $\mathrm{X}$ & & & $X$ & & \\
\hline-4 & tiying jajang & Not identified [Poaceae] & & & & & $\mathrm{X}$ & & & & & & $\mathrm{X}^{3}$ & & $\mathrm{X}$ \\
\hline-4 & base & Piper betle L. [Piperaceae] & $x$ & & & & & & & $X$ & & & & & $x$ \\
\hline
\end{tabular}

nana leaf (Figure 10). Therefore, to make canang sari, half the volume of coconut leaflet and no banana leaf is required compared with canang ceper.

\section{Occasional rituals}

Besides offering canang to ancestral spirits and gods at daily prayer, there are two most important offerings: penjor and sanggah cucuk for Dewi Sri. The penjor ritual offering is usually decorated for the galungan, which is a ceremony to welcome the return of ancestral spirits, rotating once every 210 days. Penjor are set up along the street on the right side of house entrances on the day be- fore galungan (Figure 12). They are made of a bamboo culm, about $5 \mathrm{~m}$ long, on which are placed offerings of rice panicles, coconut drupes, coconut leaves, and fruit or vegetables decorated with yellow-colored cloth. The bamboos for penjor were identified as tiying ampel (Bambusa vulgaris Schrad. ), tiying tali (Gigantochloa apus (Schult.) Kurz), tiying jelepun (Gigantochloa robusta Kurz), and tiying santong (Gigantochloa atter (Hassk.) Kurz). Coconut leaflets used to decorate penjor, mostly yellowish-white and green in color (slepan and busung), are used in various ways. For example, they may be rolled up the bamboo pole, bundled to hang, embellished like a bouquet, or arranged into a globe (Figure 12). For penjor, 


\section{Miyaura et al. - A Particular Silhouette of Human-Influenced Coconut Trees in 415 Hindu Bali, Indonesia}

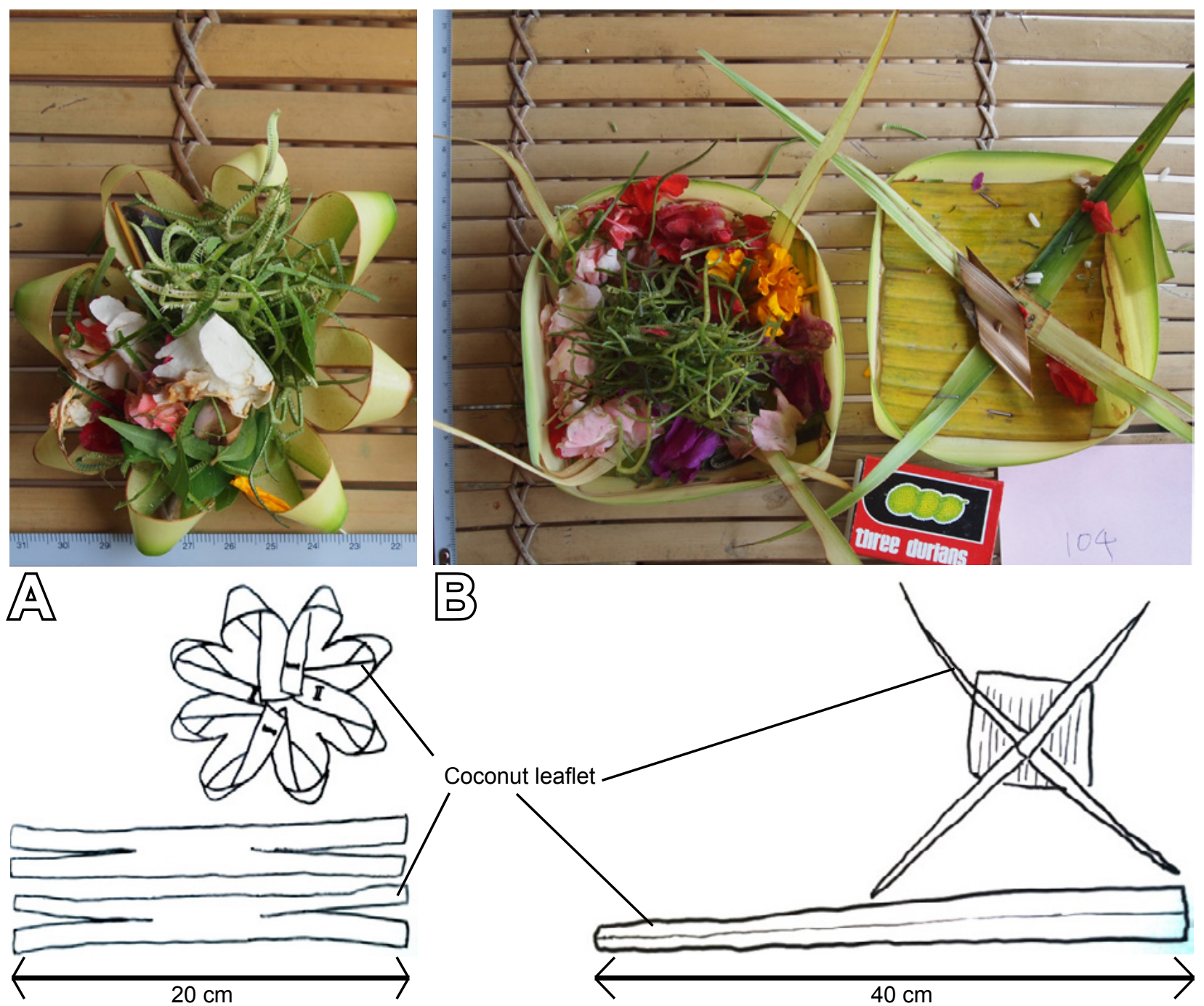

Figure 10. Frames of canang sari (A) and canang ceper (B) made of coconut leaflets in Bali, Indonesia.

the fan-shaped leaf of the ental (Borassus flabellifer L., Arecaceae) is used as a supplemental decoration, as well as the pacah flowers and endong leaves.

Sanggah cucuk for Dewi Sri is the other important occasional offering made at the harvest and planting of rice (Figure 13). Similar to penjor, sanggah cucuk has a display shelf for offering materials or foods to honor the paddy goddess, Dewi Sri. Sanggah cucuk is composed of many plant materials such as bamboo, banana leaves, endong, puring leaves, and coconut leaflets. In addition, cooked rice, fruits, and flowers are arranged on the platform. Arranged coconut leaves vary in color from green to pale yellow or yellow with green bands, as in sanggah cucuk. Yellow arrangements are designed using young coconut leaflets, often banded with mature green leaflets, with endong leaves for a red or scarlet color, and puring, biyu, and kladi (Colocasia esculenta (L.) Schott) leaves for green. In contrast to the simple arrangement used for canang, skilled workmanship is required to prepare the leaves for the special occasions, penjor and sanggah cucuk.

\section{Discussion}

As described above, large volumes of coconut leaflets are used for many types of offerings in Bali (Table 4, Figures 9-13). In addition, Balinese people offer coconut leaflets to honor the gods at ritual ceremonies to celebrate passage from birth to adulthood, for ancestor worship, at the ordainment of priests, and to protect against negative spirits (Bagus 1979), at pernama and tilem (ceremonies of the full moon and new moon, respectively), kuningan (10 days after galungan), nyepi (new year in the saka calendar), for house construction, to maintain padi for storage of harvested rice grain, and for tooth filing (Nagafuchi 1988, Yoshida 2005). However, the coconut leaflets are 


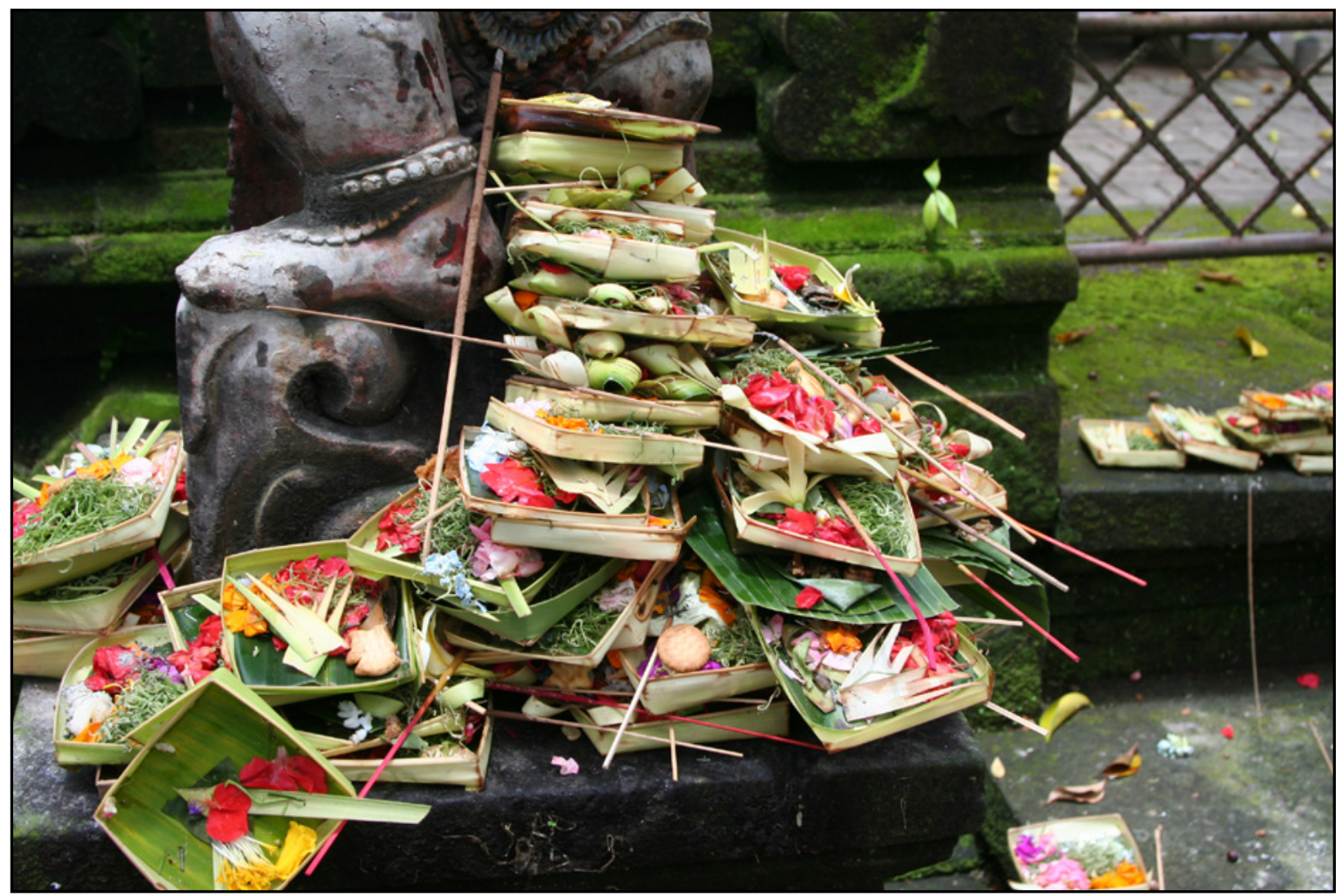

Figure 11. Canang ceper offered at the foot of a stone Ganesha in a Hindu temple in Bali, Indonesia.

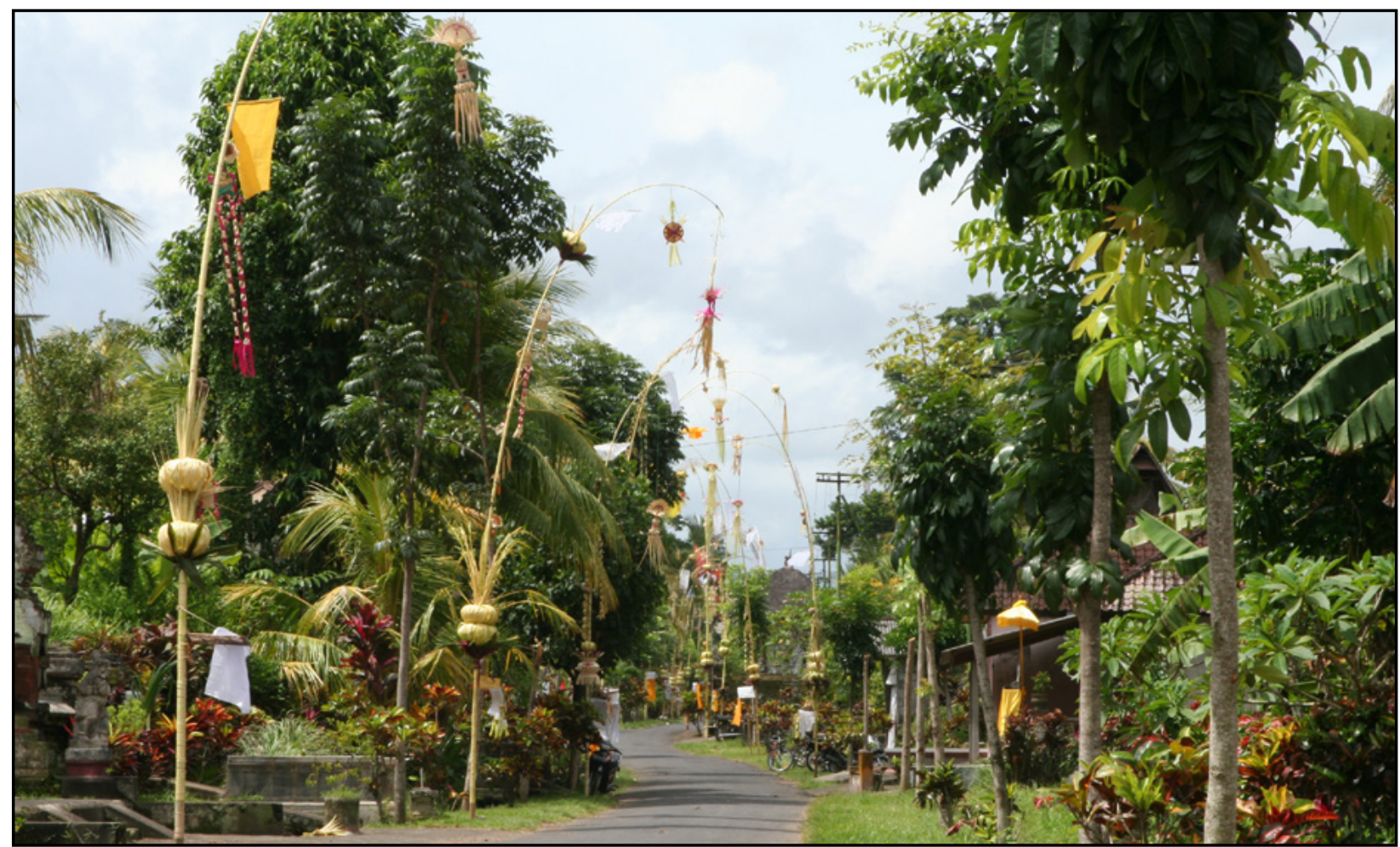

Figure 12. Penjor made from coconut leaves and bamboo in galungan, Bali, Indonesia. 


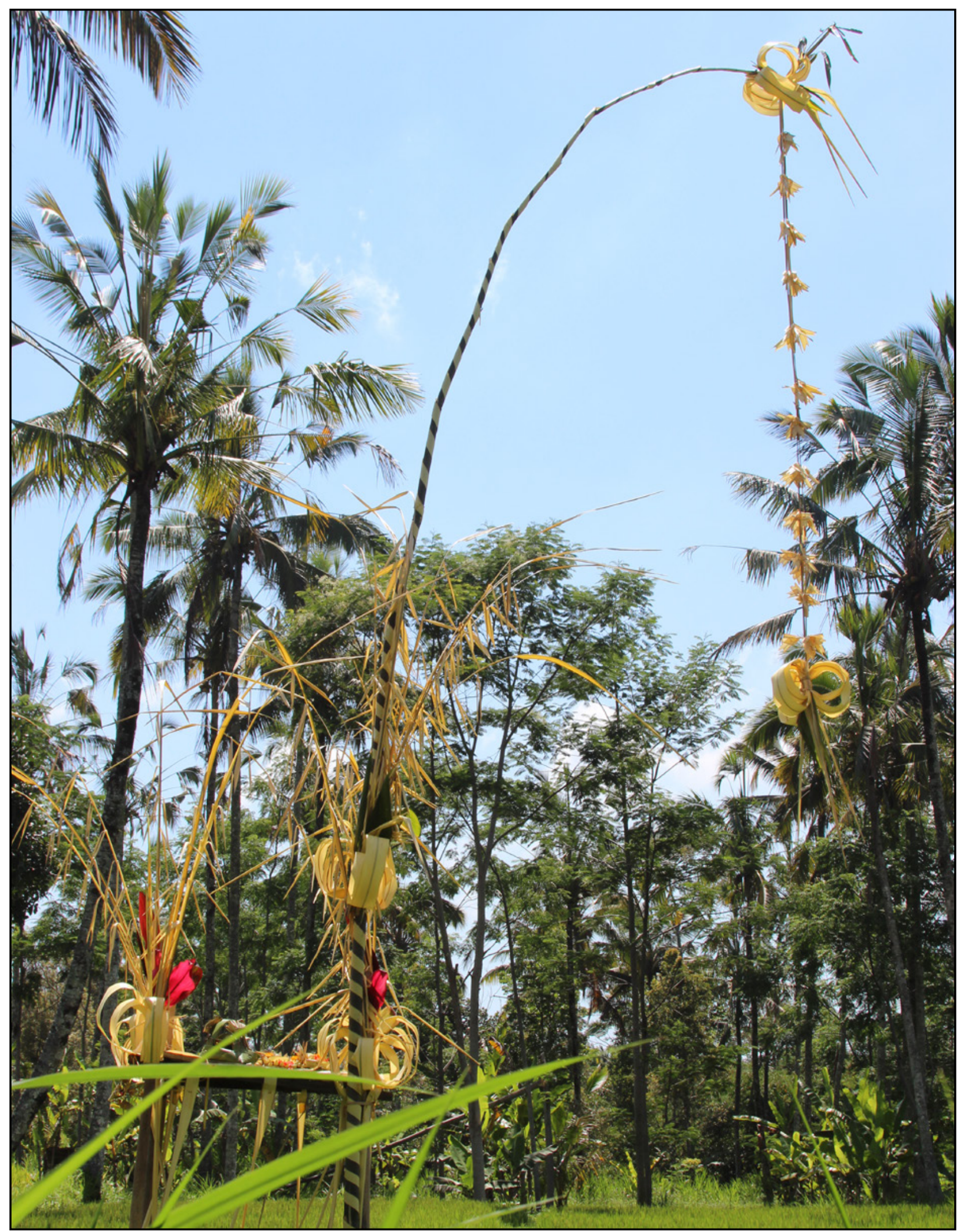

Figure 13. Sanggah cucuk for dewi sri in a rice paddy in Bali, Indonesia. A dragon is arranged to hang down from the top of the bamboo pole. The bottom cage is for offerings. 
treated and arranged differently for canang, penjor for galungan, and sanggah cucuk (Brinkgreve \& Stuart-Fox 1992, Stuart-Fox 1974, Suge 2001).

The Balinese ritual use of coconut differs from that in the Hindu societies of India and Nepal where the fruit is used for ceremonial purification (Joshi \& Chandra 1989). In contrast, Balinese Hindus use water with aromatic flowers (kumkuman) for purification and young coconut water (toya bungka) for completion and cleansing (Bateson \& Mead 1942, Yoshida 1999). This difference may reflect the persistence of indigenous (pre-Hindu) elements in Bali (Geertz 1973). Coconut leaflets are used as the base on which to place offerings of colorful flowers to the gods, reflecting the special meaning of Bali's Hindu cosmic laws (Brinkgreve \& Stuart-Fox 1992, Ramseyer 1977). The offerings involving coconut leaflets are composed of several colorful, aromatic plants and other food materials to express appreciation to the gods. For example, every canang type had a central spirit, porosan (Brinkgreve \& Stuart-Fox 1992, Eiseman 1989), which was called gorosang in the 1930s (Bateson \& Mead 1942). The porosan, the most important and sacred part (Figure 10B), is hidden by colorful and fragrant elements invisible from the outside and is made by using about $2 \mathrm{~cm}$ of folded young coconut leaflets placed inside a small piece of base (Piper betle L.) leaf together with lime, as a symbol of natural elements. The plant materials for canang consist of green or colorful leaves and flowers (Table 4, Figures 9-11) of ornamental plants as described by Darmadi (2004, 2009).

The major species for ritual offerings including coconuts, pandan, banana, and bamboo are indigenous to Southeast Asia, while several species are from temperate Asia and the Americas (Table 4). The local use of bamboo for ritual purposes was commonly known (Arimasa 2010). However, bamboo species used for penjor offerings include species widespread in tropical Asia, B. vulgaris (Ohno \& Yamaguchi 2009), and Gigantochloa species native to the islands. The bunga pelung, which originated in East Asia and is cultivated in the highlands of Bali, was observed as being used for its blue color. In contrast, pucuk barak from temperate Asia is planted and used in the highlands but was not widely seen in other areas. The diverse ornamental species of leaves and colorful, aromatic flowers such as sandat (Cananga odorata (Lam.) Hook.f. \& Thomson) and cepaka may belong to the elemental species of the Austronesian Ornamental Flower Culture Center (Nakao 1999). This diversity center may have been established as far back as the pre-Hindu period, and native plants in this area are predominantly reproduced by vegetative propagation.

People formerly made offerings by themselves, but more recently many are outsourcing the task to reduce work at home (Nakatani 1999, Poffenberger \& Zurbuchen 1980). Although external dependence on the making of offerings seems to be increasing, some of those interviewed clearly responded that they did not want to buy ready-made offerings to avoid the risk of stolen products or having canang without porosan. In all these ways, Balinese people express their appreciation to the gods by using colorful flowers, aromatic plants, and coconuts (fruit and leaves) in daily life and for special occasions. Through the special shape of coconut trees in their landscape, their own values are reflected back to them in and through their environment.

Coconut leaflets are easy to use to make many styles of decoration (Ngoerah 2002, Raras2006). One 120 cmlong leaflet of busung can be used to make at least five frames of canang sari and two frames of canang ceper. An interview with six people revealed that an average of 38.5 (range 15-70) canang per household are used for daily prayer. A bunch of busung costing 10,000 Rupiah (US \$1.0) provides 350 frames of canang sari and 140 frames of canang ceper (Figure 10). If 70 leaflets can be obtained from one harvest of both sides of the central rib of a coconut leaf, canang sari can be prepared for nine days and canang ceper for 3.6 days per household. Because new coconut leaves emerge at a one-month interval, at least 3-9 coconut trees are needed to provide each household for daily canang. Therefore, when land and labor are limited, it may make sense to buy ready-made canang sari, which cost about 120 Rupiah in a village stall, shop, or market.

As a result of the widespread use of coconut leaflets, $22 \%$ of coconut trees show a particular silhouette that was observed at nearly $70 \%$ of the study sites on the island of Bali (Table 1). In the western and eastern parts of the island, the numbers of coconut tree have decreased and are being replaced with ental. People in Karangasem planted ental for making ental sugar and the distilled liquor arak. The lower frequency of cut-leaved coconut trees in sites No. 1, 2, and 3 could be a result of the substitution of palms (Table 1). In addition to this substitution, Jembrana is a place of mixed Hindu and Javanese culture (Swellengrebel 1960), and the lower population of Hindus may be the reason behind the lower ratio of cut-leaved coconut tree at sites No.16, 17, and 18 (Table 1). In Kecamatan Kintamani (1170 m above sea level) at higher elevations where coconut palms do not grow, jaka (Arenga pinnata (Wurmb.) Merr.) leaves were cut and consumed in a similar manner to those of the coconut palm.

Harvesting of the coconut leaf creates a special coconut canopy, and this canopy silhouette creates a special landscape in the environment, which has long appeared in photographs in books, although there was no awareness of the uniqueness of this effect to Bali. A unique illustration of the cut-leaved coconut tree is seen in the photographs taken by Covarrubias (1937) and in Dutch postcards produced at the beginning of the 20th century (Haks \& Wachlin 2011). A similar canopy shape was found in the pictures of the Nakao Sasuke Slide Database (N76-113-15 


\section{Miyaura et al. - A Particular Silhouette of Human-Influenced Coconut Trees in 419 Hindu Bali, Indonesia}

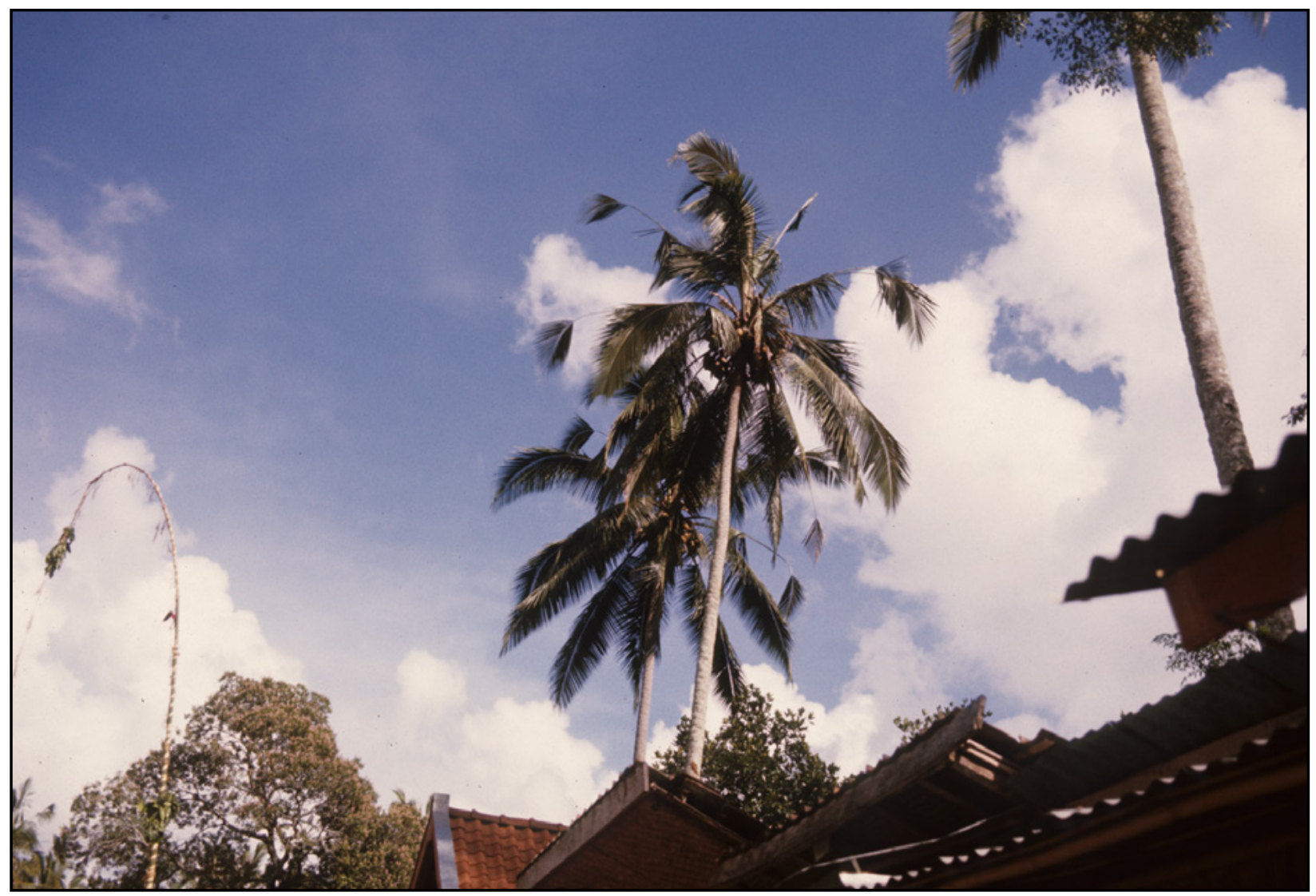

Figure 14. Cut-leaved coconut tree taken by Nakao Sasuke in Bali, Indonesia. (N76-113-15, Nakao Sasuke Slide Database 2014).

and N76-114-08), taken in 1976 in Bali (Figure 14). Therefore, the evidence suggests that this particular landscape has long been part of the Bali islands, at least since the beginning of the 20th century, and indicates the presence of human impact on coconut trees. As mentioned above, continuous and heavy use of coconut leaves for diverse ritual offerings as a fundamental element of conventional human culture may underline the shaping of the particular canopy silhouette in the Bali islands.

\section{Literature Cited}

Agung, I.A.A.G. 1991. Bali in the $19^{\text {th }}$ Century. Yayasan Obor Indonesia, Jakarta, Indonesia.

Arimasa, I.B.K., A. Kurniawan, I.N. Lugrayasa, N.M. Suradi, I.M. Sutama \& I.G. Tirta. 2007. Eksplorasi dan Inventarisasi Tumbuhan Upacara Agama Hindu di Kabupaten Badung-Bali (Exploration and Inventory of Ritual Plants for Hinduism in Kabupaten Badung-Bali). Laporan Teknik Program Perlindungan dan Konservasi Sumber Daya Alam Kebun Raya "Eka Karya” Bali, Indonesia.

Arimasa, I.B.K. 2010. Bamboo diversity and utilization in Balinese rituals at Angsri village-Bali, Indonesia. Bamboo Science \& Culture 23(1):29-37.
Astuti, I.P., S. Hidayat \& I.B.K. Arimasa. 2000. Traditional Plant Usage in Four Villages of Bali Aga Tenganan, Sepang, Tigawasa, and Sembiran, Bali, Indonesia. Botanical Gardens of Indonesia (Kebun Raya Indonesia)-LI$\mathrm{PI}$, Bogor, Indonesia.

Bali Statistics. 2014. Badan Pusat Statistik, Provinsi Bali (Central Statistical Bureau, Province of Bali). http://bali. bps.go.id. Accessed 10 September 2014.

Bagus, I.G.N. 1979. Kebudayaan Bali (Balinese culture). Pp. 279-299 in Manusia dan Kebudayaan di Indonesia (Humans and Culture in Indonesia). Edited by Koentjaraningrat. Djambatan, Indonesia.

Bateson, G. \& M. Mead. 1942. Balinese Character: A photographic analysis. New York Academy of Science, New York, New York, U.S.A.

Belo, J. 1935. A study of customs pertaining to twins in Bali. Tijdschrift voor Indische Taal-, Land-en Volkenkunde 75:483-549.

Belo, J. 1953. Bali: Temple Festival. University of Washington Press, Seattle, Washington, U.S.A. 
Brinkgreve, F. 1997. Offerings to durga and pretiwi in Bali. Asian Folklore Studies 56(2):227-251. dx.doi. org/10.2307/1178726

Brinkgreve, F. \& D.J. Stuart-Fox. 1992. Offerings: The ritual art of Bali. Image Network Indonesia, Bali, Indonesia.

Cooper, J.C. 1978. An Illustrated Encyclopedia of Traditional Symbols. Thames and Hudson, London, U.K.

Couteau, J. 2005. Bali Today 2: Love and social life. KPG press, Jakarta, Indonesia.

Covarrubias, M. 1937. Island of Bali. Alfred A. Knopf, New York, New York, U.S.A.

Darmadi, A.A.K. 2004. Keanekaragaman tanaman hias bunga sebagai penyusun canang (Diversity of ornamental plants flowers for composing canang). Pp. 225-226 in Prosiding Seminar Konservasi Tumbuhan Upacara Agama Hindu (Proceedings of Seminar on Plant Conservation for Hindu Religious Ceremony). Edited by M. Siregar, H.M. Siregar, I.W. Sumantera, I.G.N.A. Wiswasta, P.K. Sutara \& W.S. Lestari. UPT Balai Konservasi Tumbuhan Kebun Raya "Eka Karya" Bali, LIPI, Bali, Indonesia.

Darmadi, A.A.K. 2009. Jenis-jenis tanaman hias bunga penyusun "canang" dengan kontroversinya (The types of ornamental plant flowers for "canang" and controversy). Pp. 512-515 in Prosiding Seminar Nasional Etnomotani IV, Keanekaragaman Hayati, Budaya dan IImu Pengetahuan (Proceedings of National Seminar on Ethnobotany IV, Biodiversity, Culture and Science). Edited by Y. Purwanto \& B.W. Eko. Bogor, Indonesia.

De Carvalho, L.M.M. 2011. The symbolic uses of plants. Pp. 351-369 in Ethnobiology. Edited by E.N. Anderson, D. Pearsall, E. Hunn, \& N. Turner, John Wiley \& Sons, Inc., Hoboken, New Jersey, U.S.A. dx.doi. org/10.1002/9781118015872.ch21

Eiseman, Jr., F.B. 1989. Bali, Nekala and Niskala. Volume 1: Essays on religion, ritual, and Aat. Periplus Editions, Singapore.

Eko, B.W. 1998. Review: Research ethnobotany in Indonesia and the future perspectives. Biodiversitas 9(1):5963.

Fujioka, Y. 1968. Rice cultivation and its rituals in Bali Island. Pp. 95-151 in Studies of the Bali Islanders: Synthetic research of the culture of rice-cultivating races in Southeast Asian countries (II). Edited by N. Miyamoto. Tokai University Press, Tokyo, Japan.

Geertz, C. 1973. The Interpretation of Cultures: Selected essays. Basic Books, New York, New York, U.S.A.
Giambelli, R.A. 1992. The coconut, the body and the human being. Metaphors of life and growth in Nusa Penida and Bali. Pp. 133-157 in The Social Life of Trees: Anthropological perspectives on tree symbolism. Edited by Rival. L. Berg, Oxford, U.K.

Haks, L. \& S. Wachlin. 2011. Indonesia: 500 early postcards. Edition Didier Millet. Singapore.

Harries, H., L. Baudouin \& R.Cardeña. 2004. Floating, boating and introgression: Molecular techniques and the ancestry of coconut palm populations on Pacific Islands. Ethnobotany Research \& Applications 2:37-53.

Heim, E. 2015. Flora and Vegetation of Bali Indonesia: An illustrated field guide. Books on Demand, Nordestedt, Germany.

Hooykaas, C.1973. Religion in Bali. E.J. Brill, Leiden, the Netherlands.

Joshi, D.P. \& M.T. Chandra. 1989. Religious and Useful Plants of Nepal \& India: Medicinal plants and flowers as mentioned in religious myths and legends of Hinduism, and Buddhism. M. Gupta, Lashkar, India.

Krause, G. 1998. Bali 1912. Pepper Publication, Singapore.

Nagafuchi, Y. 1988. Kumotsu no sekai- balito, Wongaya Gede mura, Mantanin Padi girei. (The world of offerings in Wongaya Gede, Bali Island, ritual of Mantaning Padi). Kikan Jinruigaku 12(3):32-41.

Nakao, S. 1999. Austronesia no kaki bunkashi (Cultural history of Austronesian ornamental flowers). Pp. 55-124 in Austronesia no Minzokuseibutsugaku Ethnobiology of the Austronesians. Edited by S. Nakao \& T. Akimichi. Heibonsha, Tokyo, Japan.

Nakao Sasuke Slide Database. 2014. Nakao Sasuke Slide Database. Library and Science Information Center, Osaka Prefecture University. Osaka, Japan. http://nakao-db.center.osakafu-u.ac.jp/. Accessed 10 September 2014.

Nakatani, A. 1999. "Eating threads": Brocades as cash crop for weaving mothers and daughters in Bali. Pp. 203229 in Staying Local in the Global Village: Bali in the twentieth century. Edited by R/ Rubinstein \& L.H. Connor. University of Hawai i Press, Honolulu, Hawai i, U.S.A.

Ngoerah, I.O.A. 2002. Canang. Upada Sastra, Denpasar, Indonesia.

Ohno, T. \& H. Yamaguchi. 2009. A note on artificial dissemination of bamboos based on a distribution pattern of Bambusa vulgaris in tropical Asia. Bamboo Journal 26:41-47. 


\section{Miyaura et al. - A Particular Silhouette of Human-Influenced Coconut Trees in 421 Hindu Bali, Indonesia}

Ottino, A. 2000. The Universe Within: A Balinese village through its ritual practices. Karthala, Paris, France.

Poffenberger, M. \& Zurbuchen, M.S. 1980. The economics of village Bali: Three perspectives. Economic Development and Cultural Change 29:91-133. dx.doi. org/10.1086/451233

Ramseyer, U. 1977. The Art and Culture of Bali. Oxford University Press, Oxford, U.K.

Raras, N.T. 2006. Menjejahitan dan Metanding. Edisi 1. (Stitching and Arranging. First edition). Paramita, Surabaya, Indonesia.

Stuart-Fox, D. J. 1974. The Art of the Balinese Offering. Penerbitan Yayasan Kanisius, Yogyakarta, Indonesia.
Suge, H. 2001. Bari-tō Dai-hyakka (Encyclopedia of the Island of Bali). TBS Britannica, Tokyo, Japan.

Swellengrebel, J.L. 1960. Introduction. Pp. 1-76 in Bali: Studies in life, thought, and ritual. Edited by Wertheim W.F. et al. W. van Hoeve, Hague, the Netherlands.

Vickers, A. 1989. Bali: A paradise created. Periplus Editions, Hong Kong.

Yoshida, T. 1999. Matūru Bantan: Bari-tō no hindū no kumotsu to girei (Matul Bangtan: Offerings and rituals of Hinduism in Bali). Academia 70:311-345.

Yoshida, T. 2005. Bari Syūkyōto Jinrui gaku-Kaisyaku gakuteki ninshiki no bouken (Balinese Religion and Anthropology: Adventure for hermeneutic cognition). Fubaisha, Nagoya, Japan. 
